\title{
Harmonious Family in the Perspective of the New Belimbing Village Community
}

\author{
Sigit Ruswinarsih ${ }^{1 *}$ Yuli Apriati $^{1}$ \\ ${ }^{1}$ Department of Anthropology Sociology Education, Faculty of Teacher Training and Education, Lambung Mangkurat \\ University, Banjarmasin 70123, Indonesia \\ ${ }^{*}$ Corresponding author. Email: sigitruswinarsih@ulm.ac.id
}

\begin{abstract}
This article describes how the mindset of rural communities tends to be normative about the concept of a harmonious family. The new Belimbing Village community is a humble society and always carries out their life in accordance with religious teachings, in this case the religion of Islam. Family harmony is the dream of every married couple. Harmony means the existence of harmony, equivalence, and harmony between men and women in the household as husband and wife. Harmony also concerns harmony with other family members, namely children. Building a harmonious household is not easy. The road to the realization of a harmonious family is not always flat, flat, smooth, and without obstacles. An understanding of a harmonious family in rural communities shows functional aspects such as love, affection, cooperation, balanced division of labor and intensive communication. Efforts to create a harmonious family are carried out by cultivating self-awareness with equality between men and women. Another factor is the awareness of the existence of other family members, so there are fathers, mothers and children. The next step is to establish communication between family members.
\end{abstract}

Keywords: family, harmonious, village community.

\section{INTRODUCTION}

"Have a good life, hopefully you will become a sakinah, mawaddah, warrahmah family." This was said to a newly married couple. In every occasion of a wedding celebration, relatives, neighbors and invited guests who attend the event always say the above sentence. A sentence that contains the meaning of happiness for the partner who gets the greeting. Greeting sentences can be directly conveyed orally and some can write them on a greeting card. This is a representation of the sympathy of the person who says it. In every community group, whether it is located in urban areas or in rural areas, giving similar words belongs to everyone. It can be said that the sentence of greeting to the bride and groom has uniformity as a popular utterance. Basically, the congratulatory sentences come from the Muslim community. Sayings that eventually become a characteristic in every wedding event.

The congratulatory sentence which is interpreted as a prayer sentence is a sentence commonly said by people. However, is the meaning of this sentence the same for everyone? This is an interesting question in the midst of this massive phenomenon.

Family sakinah, mawaddah, warrahmah, are common concepts and everyone knows and uses them. Mainly among the Muslim community. The concept of sakinah is synonymous with the notion of a harmonious family in the view of the general public. Judging by the locality of the community, urban and rural communities are divided geographically. People in urban areas are accustomed to receiving the incessant incoming information from various sources. The situation will be different from the people who live in rural areas. The flow of information traffic is not as intense as in urban areas. This thought raises the desire to know factually what the village community thinks about the concept of a harmonious family or sakinah, mawaddah, warrahmah.

Urban communities are known as communities with high heterogeneity, while rural communities are communities labeled as homogeneous. Now, in this homogeneous rural community, does every villager have the same view of a harmonious family? How can this meaning be part of the various actions they take later?

The writing is limited to the theme of the meaning of a harmonious family by the people of Belimbing Baru Village, Sungai Pinang District, Banjar Regency. Exploring a meaning begins with understanding and knowledge of concepts. The meaning of the concept can be known from the point of view of a person or group of related people. The behavior of a person or group of people then reinforces the perspective on the concept.

This paper is intended to obtain a description of the concept and behavior of a harmonious family in the community of Belimbing Baru Village, Sungai Pinang District, Banjar Regency. Knowledge of the profile of a harmonious family in the community of Belimbing Baru Village includes an overview of the concept of a harmonious family in the view of society and community behavior in realizing a harmonious family and their efforts to make it happen. This knowledge can be used for the development of the principles of family social governance. 


\section{THEORETICAL FRAMEWORK}

Humans become part of a family that is always in touch with each other every day. This situation needs to be fully realized that each individual is part of the family and in the family all can be expressed without significant obstacles [1].

The family as the most important primary group in society is a group that is formed from the relationship between men and women. The relationship has more or less taken a long time to create and raise children. A family in its pure form is a social unit consisting of a husband, wife and children who are not yet mature. Another opinion from Ahmadi [2] states that the family is the smallest social unit consisting of husband and wife who are bound by a marriage, which is complemented by the presence of children as a result of the marriage or the absence of a child.

Helmawati [3] states that the family is a small group that has a leader and members, has a division of tasks and work, as well as rights and obligations for each of its members. Family is the first and foremost place where children learn. From their families, they learn faith-related qualities, noble qualities, communication and interaction, and life skills.

Said by Horton and Hunt [4] that the nuclear family is a family that only consists of father, mother, and children obtained from their offspring or adoption or both. The nuclear family is also termed the batih family. Conjugal Family (batih family) is based on the bond of marriage and consists of a husband, a wife and their unmarried children. Stepchildren and adopted children who legally have the right of authority to more or less the same as their biological children, can also be considered as members of an extended family or nuclear family.

Thought of Burgess and Locke quoted by Khairuddin [5] about the characteristics of the family found in all families and also distinguishes families from other social groups, namely as follows:

1. The family is the composition of people who are joined by marriage, blood, or adoption.

2. Family members are characterized by living together under one roof and constituting the composition of one household, or if they live, the household is their home.

3. The family is a unit of people who interact and communicate who create roles for husband and wife, father and mother, sons and daughters, brothers and sisters.

4. The family is the custodian of a common culture, which is essentially derived from the general culture, but in a complex society each family has different characteristics from other families.

Alfani Daud [6] tells that the Banjar people adhere to Islam and they are indeed among those who are relatively devout in practicing their religion. In this understanding, urang Banjar will take actions in accordance with Islamic teachings. In connection with building a family, urang Banjar is also based on Islamic teachings. Daud explains on the next page that marriage is almost a sacred act for the Banjar people and must be lived by everyone.

According to Shihab [7]the sakinah family doesn't just come, but there are conditions for its presence. Sakinah family is a bond of living alliance on the basis of marriage between adults of different types who live together and live in a household with the driving force in building a family order that can provide comfort in the world as well as guarantee the safety of the hereafter.

The factors needed in forming a sakinah family, among others [7]:

1. Equality, like equality in humanity. The term used to denote togetherness and partnership at the same time indicates that a man alone or his own husband is not perfect yet, as well as a woman, before joining with his partner is also only partly. They are only perfect when they come together and work together. Allah's blessing "mixing" occurs thanks to the cooperation and willingness of each to reveal the deepest secrets, and this could not have happened without a partnership between the two.

2. Deliberation, families form and develop new social relationships through the line of marriage lines. Humans live in society bound to the norms that exist in society. Marriage is successful if both partners have the awareness that living together is take and give, that life in a household even though it is accompanied by various problems is much better than living separately. The various problems faced must be resolved by deliberation on the basis of the equality of both parties.

Awareness of partner's needs Each married couple can find a sense of love, love, affection and sympathy that they cannot get anywhere else. Peace of mind and affection that humans feel for their partners is one of the psychological demands that cannot be separated from every human being and cannot be found other than in the institution of marriage. A different type of calm, namely the serenity of the soul of their partner, so that it is as if the souls of the two are united and their hearts are united into one soul and one heart.

\section{METHOD}

\subsection{Research Approach}

The method used in this research is qualitative method. Qualitative methods can be defined as research that produces a description of spoken and written words of behavior that can be observed from the people studied. As stated by Bogdan and Tylor [8] that qualitative research is a research procedure that produces descriptive data in the form of written or spoken words from people and observable behavior.

Qualitative research is rooted in the interpretive paradigm initially arising from dissatisfaction or reaction to the positivist paradigm at the root of quantitative research [9]. Faisal [10] emphasized that qualitative research is in the form of a cycle and provides the possibility to redesign or 
be open in nature, besides that data collection and analysis take place simultaneously.

This qualitative method is used to describe the harmonious family more deeply from the perspective of the village community itself. Research carried out in depth can reveal the meaning from the perspective of the people studied and also the various actions they take in an effort to realize that perspective.

\subsection{Research sites}

This research was conducted in the area of Belimbing Baru Village. Belimbing Baru Village is one of the villages located in Sungai Pinang District, Banjar Regency, South Kalimantan province with an area of 5,700 hectares which administratively consists of 5 RTs, this village can be reached in approximately 4 hours from Banjarmasin City by car or other vehicle. Judging from its utilization, the land in this village area consists of: settlements, forests, plantations and others.

The people here are classified as devout Muslims. As urang Banjar, they naturally explore the nature of being a wellknown religious community in their daily lives. The household situation of the population can be said to be harmonious because there is rarely a separation between husband and wife in Belimbing Baru Village. According to the Village Secretary, in the last ten years there have been no divorce cases in his village. Life in the household of the Belimbing Baru Village community is also filled with a very visible sense of togetherness and warmth. They usually do household chores by working together and distributing tasks between each family member. In addition, religious nuances appear to color the lives of the residents of Belimbing Baru Village.

The data collected in this study are the people's views on harmonious families and people's behavior as a harmonious family. The data which is the source of research are primary and secondary data. Primary data is data that is collected directly from interviews with informants of family members who are members of Belimbing Baru Village. Secondary data were obtained from documents related to the research theme. In this study, secondary daa collected through documentation techniques are also needed.

The informants in this study were selected purposively. Purposive technique is to select informants deliberately with the special considerations of the informants. The use of this technique is based on knowledge of certain known traits obtained from previous populations. Informants are selected in their relationship as a family in the village of Belimbing Baru, so that they can be considered to have knowledge of the object of research. In this study, the informants were people who were married. Informants with profiles as follows:

a. Subaniah, 35 years old

Ibu Subaniah has been married for more than seventeen years and has 3 children, respectively 17 years, 8 years and 4 years. Her husband is named $\mathrm{Mr}$ Sarkani. Subaniah married because her parents arranged marriage and married at a young age. In his daily life, he works as a small trader in the village who opens a drinking shop during the day, while his husband works in a rubber plantation.

b. Haji Yusran, 50 years old

Mr. Haji Yusran has been a family for decades. His first wife passed away and then he remarried a widow from Kampung Jawa (Martapura). From his first wife, he has 6 children and 5 of them are married. His last child is currently studying at the Darussalam Martapura Islamic Boarding School. Everyday he works as a member of the Village Consultative Body (BPD).

c. Rahmat, 30 years old

Mr. Rahmat has been married for 6 years and has 1 child aged 5.5 years. His wife is named Helmina (39 years), a civil servant (Principal in SMA). In his daily life, Mr. Rahmat works as the Secretary of the New Belimbing Village.

d. Khairurroji, 29 years old

Mr. Khairurroji has been married since 2007. His wife is Helma (26 years old). They have been blessed with 2 sons named Muhammad Hafiz (10 years) and Muhammad Rehan (3 years). On a daily basis, Mr. Khairurroji serves as the Head of the New Belimbing Village (since 2013). His wife is a housewife and owns a kiosk selling groceries. At Mr. Khairurroji's house there were 6 people, namely his father and mother, the couple Mr. Khairurroji and Mrs. Helma and their two children.

\subsection{Research methods}

Interviews with informants were conducted using semistructured interview techniques. This interview uses a guide that contains an outline of the research question then the questions develop according to the conditions in the field. Through this interview, informants were asked about their views on harmonious families and daily activities that are interconnected and can also be traced to things that may be hidden in the informant. In addition, data was also collected through FGD (focus group discussion). The informants were gathered at the same time and place and then they were asked the same questions. Various data can be collected from this forum. Documentation is carried out by tracing documents related to research topics as well as records of informants' daily activities.

Data analysis in qualitative research was carried out before entering the field, during the field, and after being in the field. Miles and Huberman [11] argued that the activities in qualitative data analysis were carried out interactively and continued continuously until the data was saturated. The data analysis technique uses the classification from Miles and Huberman, namely the data reduction stage, the data presentation stage and the conclusion stage.

The data credibility is done by using triangulation technique. Triangulation that is done is triangulation of sources and triangulation of techniques. Different data sources but still within the scope of the research topic can be a way of triangulating sources. In technical triangulation, 
several techniques were carried out to confirm data, namely interviews, FGDs and related document support.

\section{RESULT AND DISCUSSION 4.1 The Views of the New Belimbing Village Community}

Mr. Khairurroji (29 years) as a resident and also the Head of the New Belimbing Village, expressed his view that a harmonious family is a family surrounded by happiness, a sense of comfort, serenity, security and is also protected by each family member. In his family, forms of harmony are reflected in the activities carried out by each family member and those activities can also be carried out together within a family member, for example cleaning the house together. The marriage that has been undertaken since 2007 until now does look very harmonious and has now entered the age of 11 years of marriage with his wife.

As stated by Suprajitno[1]that humans are part of a family that is always in touch with each other every day. Every individual is part of the family and in the family all can be expressed without significant obstacles. In Pak Khairuroji's family, a sense of affection is expressed by mutual awareness of the role of husband and wife in caring for and maintaining comfort in the family. This family feels awareness of being a family as a form of togetherness that is always maintained. Togetherness and cooperation as a form of protection for family members is always maintained by Pak Khairuroji. This family view implies the meaning of a harmonious family in their perspective.

The next view was expressed by Mrs. Subaniah, who is 35 years old, she works as a snack seller in Belimbing Baru Village. In his family there are 5 family members consisting of husband, wife, and 3 children. He revealed that a harmonious family is a family in which there is a sense of love and affection between family members, then in the family there are also behaviors that help each other family, for example helping in doing household chores, but there are also There is a division of duties between the families so that in the house there is always communication and agreement in terms of taking care of the household chores. Ibu Subaniah's family situation emphasizes personal communication and agreement in household work. According to Helmawati [3] in a family that has leaders and members, has a division of duties and work, as well as rights and obligations for each of its members. Family is the first and foremost place where children learn. From their families, they learn faith-related qualities, noble qualities, communication and interaction, and life skills. Love, compassion and cooperation within the family of Ibu Subaniah illustrate the harmony that this family yearns for. The rights and obligations of family members are considered and the very strong linkages between the members of the family. The basis for a harmonious family was instilled by the couple, Ibu Subainah, so that the children too could feel happiness.

Not much different from the two informants above, Mr. Rahmat, who is 30 years old, serves as the secretary of the New Belimbing Village every day, argues that a harmonious family is a family that is always surrounded by love and affection in a family, and there the comfort felt by each family member, so that even in the family there are rarely problems that occur, even if there are problems in a family, they can be resolved quickly and precisely by the family in a cold head without anger overcoming them.

Helmawati's opinion [3] confirmed by Pak Rahmat in his harmonious family. That they learn belief-traits, noble qualities, communication and interaction, and life skills, in family life. Love and affection were the basis for Pak Rahmat to start his household. Although at first Pak Rahmat was not trusted to be the partner of his present wife, he persistently tries to guide his wife and children with love and affection. It is this deep feeling that can provide comfort for family members so that household problems in any form can be tackled together.

Such is what Burgess and Locke said [5], the harmonious family in Belimbing Baru Village fulfills the criteria regarding family characteristics that exist in all families and also differentiates families from other social groups. The family is the composition of people who are joined by marriage and blood. Family members are characterized by living together under one roof and sometimes several relatives such as parents, in-laws, relatives, wives or husbands also reside in their residence. The household is their home. This kind of family can be found in almost all parts of Indonesia. This shows the extent of community kinship.

The family in Belimbing Baru Village is always a unit of people who interact and communicate who create roles for husband and wife, father and mother, sons and daughters, brothers and sisters. The family is the custodian of a common culture, which is essentially derived from the general culture, but in a complex society each family has different characteristics from other families. The characteristics of love, affection, cooperation, comfort, communication, division of labor, each of which are completely present in every family. The only difference is that the most prominent characteristics in a family are often different from other families.

\subsection{The Efforts of the New Belimbing Village Community to Realize the Concept of a Harmonious Family}

Mr. Haji Yusran (50 years old), a member of the BPD of Belimbing Baru Village, revealed that there are several efforts that can be made to create a harmonious family. In the village of Belimbing Baru, the majority of the residents get married at a very young age, even below the standard age of marriage that has been established by statutory regulations. Therefore, these young couples are sometimes still unstable and still can't control their respective egos. In terms of the realization of a harmonious family, the parents of each pair play an important role in it. Parents have the duty to supervise and protect the domestic life of their children and carry out solutions if there are problems in their children's families.

Marriage for villagers occurs because they realize that they have reached the stage of living in pairs. Equality factors, such as equality in humanity. Awareness of the different 
roles of men and women but in equality. The term used to denote togetherness and partnership at the same time indicates that a man alone or his own husband is not yet perfect, as well as a woman, before merging with his partner is also only partly. A man who already has an income and feels able to support a wife and children who will be born will need a partner. Even if it is seen from the point of view of age that it is not enough to get married, there is a realization that they need a partner to continue their life.

The role of husband and wife is also very influential on the realization of a harmonious family, namely by maintaining mutual trust between each partner, and also taking time each day to gather and chat together is one of the driving factors for the creation of a harmonious family. Husband and wife become the main pillar in the family and can make a harmonious family. As said by Shihab [7] that a bond of living communion on the basis of marriage between adults of different types who live together and live in a household with the driving force in building a family order that can provide comfort in the world as well as guarantee the safety of the hereafter.

Marriage is a sacred thing. Villagers do not hesitate to marry off their children who have grown up or in their teens. If a boy, as long as he can work and have an income, the next thought is marriage. The main livelihoods of the villagers are agriculture and plantations. Working in that field has become a kind of tradition. Parents will pass agricultural and agricultural knowledge and skills to their children. The traditions and culture of farming and gardening have continued from generation to generation. There is no concern or worry for the parents about the future of their children. They believe, as long as the land is properly cultivated, it will bring good fortune. This is the view of the villagers so that it makes everything easier for their generation to continue their life and marriage [6] that as a Banjar community that adheres to Islam and includes people who are relatively devout in practicing their religion. In this understanding, the villagers as urang Banjar will take actions in accordance with Islamic teachings, especially in terms of building a family. It can be emphasized by Daud that marriage is almost a sacred act for urang Banjar and must be lived by everyone.

The education of a child is also important, especially in the religious field in particular. When a child is a child, his parents will teach him the Koran at home. When he grows up, the child will be sent to school in the Koran Reading Park so that his religious knowledge will be wider and more extensive. Helmawati[3]classifies the family as the first and foremost place children learn. Starting from this family, children learn about life and life, love, togetherness, loyalty, cooperation and good things.

As a family, when attending events, such as weddings and community thanksgiving, Mr. Haji Yusran's family usually comes to attend these events together. In order to maintain closeness between family members. Activities in the family are usually carried out together, such as gathering to eat together. Although most of his children are married to each other and have their own homes, they can still make time to gather with their extended family. In order to create warmth in the family.
The factors that play a role in family harmony are guarded by Pak Yusran. That togetherness in various activities shows awareness of a partner's needs. The warmth in togetherness in activities is felt by the family as part of the affection between family members. Peace of mind and affection that humans feel for their partners is one of the psychological demands that cannot be separated from every human being. The serenity and warmth shows as if the souls of family members are united and their hearts are united into one soul and one heart.

Mr. Khairurroji (29 years), revealed that the dream of every couple who builds a household is of course to create a harmonious family, which is filled with happiness and a sense of love and comfort. For that, it is necessary to make several efforts so that the desired goals are achieved. Communication between partners is very important in maintaining harmony in the family. Before he served as village head, he worked far from the family, so that communication with the family, especially with his wife, must be strictly maintained for the continuity of married life. Apart from communication, commitment is also an important thing in married life. Couples who have committed to be faithful for life will create a sense of trust in each partner within them.

Family problems can always be solved if they meet the conditions faced with a cold head. The factor that plays a role in this situation is the capacity for deliberation. The family forms and develops new social relationships through the lines of marriage. Problems that arise can be communicated together through deliberation. Problems will always arise because humans live in a society bound to the norms that exist in society. Norms sometimes go differently from human desires, so problems arise, so strong communication and commitment between family members needs to be fostered. Marriage is successful if both partners have the awareness that living together is take and give, that life in a household even though it is accompanied by various problems is much better than living separately.

\section{CONCLUSION}

The view of the people of Belimbing Baru Village states that a harmonious family is a family full of love and affection. Harmonious families have cooperation and pay attention to the division of labor in the family. Harmonious families also place importance on intensive communication between family members. Love and affection provide comfort and warmth in a harmonious family.

The efforts of residents in forming a harmonious family are continuously being made. The main factor is the awareness of equality between men and women. Each party is aware of its existence and feels the need for each other. Differences in partners become a strength to complement each other. The second factor is striving for togetherness in every family activity. This shows an awareness of the existence of other family members. That they are a family that need and care for each other. The next factor is striving for communication within the family. Communication is very necessary so that there is cooperation in the family. 
Communication becomes the basis for conducting deliberation in every problem faced by the family.

\section{ACKNOWLEDGMENT}

Thank you to the Dean of FKIP, Lambung Mangkurat University who has given support to participate in international conferences. Thank you to colleagues in the Anthropology Sociology Education Study Program who are always encouraging.

\section{REFERENCES}

[1] Suprajitno, Family Nursing Care,, Jakarta: EGC, 2004.

[2] A. Ahmadi, Developmental Psychology, Jakarta: Rineka Cipta, 1991.

[3] Helmawati, Family Education, Bandung: Rosda Karya, 2004.

[4] D. Narwoko and B. Suyanto, Sociology of Introductory and Applied Texts, Jakarta: Kencana Prenada Media Group, 2007.
[5] Khairuddin, Family Sociology, Yogyakarta: Liberty, 2008.

[6] A. Daud, Islam and Banjar Society, Jakarta: Rajagrafindo Perkasa, 1997.

[7] MQ Shihab, Grounding the Qur'an (The Function of Revelation and the Qur'an in Community Life, Bandung: Mizan, 2006.

[8] Margono, Educational Research Methods, Jakarta: Rineka Cipta, 1997.

[9] B. Suyanto and Sutinah, Sociological Research Methods: Various Alternative Approaches, Jakarta: Kencana Prenada Media Group, 2015.

[10] S. Faisal, Qualitative Research, Malang: YA3, 1990.

[11] M. Miles and M. Huberman, "Data Management and Analysis Methods," in Handbook Of Qualitative Research, Yogyakarta, Pustaka Pelajar, 2000, pp. 591-592. 